\title{
A study of factors associated with tokophobia and its effect on pregnancy
}

\section{Padmasri Ramalingappa, Raksha S. Gowda*, Shruthi Holavanahalli Srinivasamurthy}

Department of Obstetrics and Gynecology, Sapthagiri Institute of Medical Sciences, Bangalore, Karnataka, India

Received: 25 November 2021

Revised: 10 February 2022

Accepted: 11 February 2022

\section{*Correspondence:}

Dr. Raksha S. Gowda,

E-mail: rakshakench12@gmail.com

Copyright: () the author(s), publisher and licensee Medip Academy. This is an open-access article distributed under the terms of the Creative Commons Attribution Non-Commercial License, which permits unrestricted non-commercial use, distribution, and reproduction in any medium, provided the original work is properly cited.

\begin{abstract}
Background: Tokophobia is pathological fear of childbirth which has bearing on the women's health with the physical and psychosocial morbidity. It includes fear of injury to the baby, genital tract, death and is a common cause for which a woman opts for caesarean section. Recognition of tokophobia and close liaison with obstetricians/specialists can help to reduce its severity and ensure treatment. Aim of the current study was to assess the incidence of tokophobia and correlation with the sociodemographic variables to evaluate the possibility of reducing the requests for caesarean section.

Methods: 150 pregnant women attending the antenatal OPD and labour ward in a tertiary care centre constituted the study population. Data was gathered using standard questionnaire to assess fear of child birth, anxiety associated and was analysed with chi-square test for statistical significance.

Results: 150 women included in the study, the incidence of tokophobia was $55.3 \%$ and severe tokophobia was $30.7 \%$. Of these $62 \%$ were primigravidae and $38 \%$ multigravidae. $15.3 \%$ of the total requested for caesarean section with the major reason being fear of childbirth. However, $84.7 \%$ of the study population did so without any such request for caesarean section. Higher incidence of tokophobia was observed in women with intermediate education as against those who completed their graduation and post-graduation.

Conclusions: Tokophobia is associated with pregnant women in different severity. It's influenced by sociodemographic variables like educational and socioeconomic status. Improvement in sociodemographic conditions could reduce tokophobia.
\end{abstract}

Keywords: Caesarean section, Fear of childbirth, Tokophobia

\section{INTRODUCTION}

Pregnancy is a major physiological event in each woman's life. Instead of joyful experience, pregnancy may turn into a worrisome and fearful event in some women and the fear may assume a pathological dimension and becomes a disease worth recognition and treatment. Majority of these women are capable of coping up with fear and anxieties on their own, societal and medical support. However, when it becomes pathological dread, it is called tokophobia. It is also known as "maieusiophobia" or "parturiphobia." This was initially described in literature by Knauer in $1897 .{ }^{1}$ About $20-78 \%$ of pregnant women report fears associated with the pregnancy and childbirth. ${ }^{2,3}$ However, $13 \%$ of non-gravid women report fear of childbirth sufficient to postpone or avoid pregnancy. Fear is more common and intense in nullipara than parous women. ${ }^{4}$

Concern is mainly because of remarkable sequelae regarding women's morbidity, the neurobehavioral development of their children, and caesarean section on 
maternal request. Fear of labour is multidimensional and may be divided into primary and secondary tokophobia. ${ }^{5}$ Primary tokophobia is the fear and deep-seated dread of childbirth which pre-dates pregnancy and can begin in adolescence. Secondary tokophobia is due to a previous agonizing experience of traumatic birth, poor obstetric practice or medical care, postpartum depression or other such contributing events, which prevents them emotionally from further childbearing. Fear of childbirth is not an isolated problem but associated with the woman's personal characteristics, mainly general anxiety, low self-esteem, depression, dissatisfaction with their partnership, and lack of support. Also, the partners of women with fear have a certain pattern of low psychological well-being, resulting in low lifesatisfaction, dissatisfaction with partnerships, and depression. ${ }^{6}$ Though there are many studies related to tokophobia and related factors in several countries or population, hardly any are reported amongst the Asian population. It's high time we start recognising, evaluating, intervening with regard to tokophobia and promote positive motherhood and here is a reflective experience.

\section{METHODS}

\section{Study design, location and duration}

This was a cohort study conducted in a tertiary centre, Sapthagiri institute of medical sciences, obstetrics and gynaecology department, Bangalore. The study was conducted from 2017-2018 over a period of one year.

\section{Sample size and selection criteria}

Total 150 pregnant women from 29 weeks or those postpartum up to six weeks after delivery attending the antenatal OPD and labour ward in a tertiary care centre were approached and were asked to complete the questionnaires related to the socioeconomic status, educational status, anxiety, delivery expectation and specific fears.

Data was collected using questionnaires, to assess the broader perspectives of effect of pregnancy and the fear of process of delivery itself. Fear of childbirth (FOC) was assessed by modified Areskog's questionnaire and pregnancy anxiety scale by Levin. Previous overall birth experience was measured using a numeric rating scale, and previous obstetric complications were assessed using an index of seven obstetric complications: emergency caesarean section, instrumental vaginal delivery, extensive blood loss, retained placenta, serious maternal infection during labour, thrombosis, and anal sphincter tears.

The subjects were interviewed with a structured Performa. Females in the reproductive age group of 1545 years, nulliparous or multiparous in the third trimester of pregnancy from $29^{\text {th }}$ week onwards up to postpartum status of six weeks following delivery were interviewed on the performa basis and were categorised as case or control based on the presence or absence of tokophobia respectively. Two questionnaires were used to assess the incidence of tokophobia: modified Areskog's score and Levin's pregnancy anxiety scale. Areskog's score: a score of 5 or more on a maximum score of 10 was considered positive for tokophobia. Levin's scale: a 5 pointer scale, categorised as mild (10-15) moderate (15-25) and severe (>25) tokophobia.

\section{Statistical analysis}

Data collected were analysed with Chi-square test for statistical significance.

\section{RESULTS}

Out of the total 150 included in the study, cases were categorised as those with tokophobia and controls as those without tokophobia. The incidence of tokophobia in the present study was $55.3 \%$ following Areskog's score and severe tokophobia as per Levin's scale was $30.7 \%$ (Table 1). Mild to moderate tokophobia was associated in $69.3 \%$ of the sample studied as against severe FOC in $30.7 \%$ using Levin's scale.

\section{Table 1: Incidence of tokophobia.}

\begin{tabular}{|lll|}
\hline Parameters & N & $\%$ \\
\hline Areskog's score & & \\
\hline Positive for tokophobia (cases) & 83 & 55.3 \\
\hline Negative for tokophobia (controls) & 67 & 44.7 \\
\hline Levin's scale & & \\
\hline Mild tokophobia & 23 & 15.3 \\
\hline Moderate tokophobia & 81 & 54 \\
\hline Severe tokophobia & 46 & 30.7 \\
\hline
\end{tabular}

The prevalence of tokophobia was correlated with sociodemographic and obstetric variables as in table 2. $62 \%$ of the women were primigravidae and $38 \%$ were multigravidae. $84.7 \%$ had term delivery; remaining $15.3 \%$ were preterm. $15.3 \%$ of the total requested for caesarean section with the major reason being FOC. However, $84.7 \%$ of the study population did so without any such request for caesarean section. Of the 150 women studied, 56.6\%belonged to upper middle socioeconomic class (SEC), 30.2\% lower middle SEC, 4.7\%upper SEC, 8.7\%lower SEC. 79.3\% women had intermediate schooling, $17.3 \%$ were graduates, and $3.3 \%$ were post graduates and $96.7 \%$ women were unemployed. FOC was seen in $45 \%$ of the women belonging to upper middle SEC, 30\% among lower middle SEC and least 2\%-7\% among lower SEC.99.3\% of the sample population were aware about the events during pregnancy, childbirth and postpartum. Very few post-graduation completes $(4.81 \%)$ had FOC. Assessment using Levin's scale also revealed higher incidence of tokophobia in women just completed intermediate education as against those who completed their 
graduation and post-graduation. Chi-square test of significance was used to test association between request for c-section and tokophobia and found that there was no association observed between tokophobia and request for C-section. Of the 150 women studied, $79.3 \%$ women had intermediate schooling, $17.3 \%$ were graduates, and $3.3 \%$ were post graduates.

Table 2: The Prevalence of tokophobia was correlated with obstetric and sociodemographic variables.

\begin{tabular}{|lll|}
\hline Parameters & N & $\%$ \\
\hline Obstetric score & & \\
\hline Primi & 93 & 62 \\
\hline Multi & 57 & 38 \\
\hline Period of gestation (weeks) & & \\
\hline Term (37-42) & 127 & 84.7 \\
\hline Preterm (28-36) & 23 & 15.3 \\
\hline Planning of pregnancy & & \\
\hline Planned & 133 & 88.7 \\
\hline Unplanned & 17 & 11.3 \\
\hline Mode of delivery & & \\
\hline Normal/vaginal & 79 & 52.6 \\
\hline LSCS & 71 & 47.3 \\
\hline Request for caesarean section & \\
\hline Yes & 23 & 15.3 \\
\hline No & 127 & 84.7 \\
\hline Socioeconomic status & & \\
\hline Upper middle & 85 & 56.6 \\
\hline Lower middle & 45 & 30.2 \\
\hline Upper lower & 7 & 4.7 \\
\hline Lower & 13 & 8.7 \\
\hline Educational status & & \\
\hline Intermediate & 119 & 79.3 \\
\hline Graduate & 26 & 17.3 \\
\hline Postgraduate & 5 & \\
\hline Employment status & 5 & \\
\hline Employed & 145 & \\
\hline Unemployed & & \\
\hline & & \\
\hline & & \\
\hline & & \\
\hline & & \\
\hline
\end{tabular}

Assessment using Areskog's scale revealed higher incidence of tokophobia in women with intermediate education as against those who completed their graduation and post-graduation.

\section{DISCUSSION}

It's common for women to dread childbirth. Some women cope up and overcome such fears. But few women have extreme fear and anxiety expressed as morbid fear of childbirth which is called tokophobia. Fear of childbirth can be seen as anxiety or phobia, the latter might manifest as nightmares, physical ailments and difficulty to concentrate on work or family activities and most often crops up as a request for caesarean section. About $5-7 \%$ of the pregnant women are affected by severe fear of childbirth. ${ }^{7}$ Tokophobia was associated with increased request for termination of pregnancy, admission for hyperemesis gravidarum, post-traumatic stress disorder (PTSD), request for sterilisation. ${ }^{8}$ Fear of childbirth has higher association with younger age, lesser education, unemployed status, smoking, single mothers and depression.

Most studies have reported increased prevalence of elective and emergency caesarean section as the mode of delivery in those with FOC. Prolonged or protracted labour has also been associated with tokophobia. When compared, nullipara was found to be more fearful than parous women both in early and late gestation. The reasons for FOC include fear of pain biologically; psychologically it's related to previous traumatic instances, fear of upcoming parenthood, personality type; socially because of lack of support an economic uncertainty or secondary to horrifying experience at previous childbirth. Quite often minor mental health problems are unknown or unidentified, but these along with FOC are the strong predictors for the need of postpartum psychiatric care. ${ }^{9}$ There is increasing incidence of delivery by caesarean section and indication of maternal request is seen commonly. ${ }^{10}$ The study of mode of delivery and relation to depression found no benefit from planned caesarean. One study indicated that women needed help to become mentally able to deliver vaginally averting their thought or wish for planned caesarean. ${ }^{11}$ An intervention RCT to promote positive motherhood using informative, relaxation and support sessions with the hypothesis of benefit reported a feasible and efficient enhancement not in just tackling FOC, but also in long term positive parenting with early child parent bonding. ${ }^{12}$

In the descriptive analysis of 150 women beyond 28 weeks up to 6wks postpartum, several factors like socio economic status, education, parity, gestational age, planning for pregnancy, awareness about pregnancy events-influencing tokophobia were considered. The main goal of our study was to observe how fear of childbirth is distributed in the representative population. The incidence of tokophobia using modified Areskog's score was $55.3 \%$. By using Levin's scale $15.3 \%$ had mild, $54 \%$ moderate, $30.7 \%$ had severe tokophobia. Few reports across the globe revealed an incidence of fear of childbirth of $20-78 \% .^{2,3}$ However severe FOC has a varied incidence of $5-7 \% .^{7}$ The enormous variation in the incidence reported in various studies could be due to the different questionnaires and scales used to assess the same, as well as the different gestational age at which women were included in the study and maybe even the post-partum period. Mean age of pregnant women was 24 years (17-35 years) in the current study.

Multiparous women had higher scores for fear of childbirth than nulliparous women in few studies. ${ }^{13,14}$ In the present study multiparous women (64.1\%) were apparently found to have higher FOC than nulliparous $(49.46 \%)$. Some of the studies indicated a high FOC quotient in nulliparous women. ${ }^{4}$ Nulliparous women are preoccupied with the fear of unknown events during 
pregnancy, childbirth and postpartum, especially of pain and harm to her or her baby. Tokophobia was significantly higher on the whole in those women who had studied up to intermediate and lesser among those with post-graduation. According to the study, we found there is no correlation between request for caesarean section and tokophobia. Women with secondary FOC were found to have 5.2 times higher probability of having a caesarean section. ${ }^{15}$ While considering mode of delivery, $52.6 \%$ had normal vaginal delivery and $47.3 \%$ underwent caesarean section. Statistically there was no significant correlation with request for caesarean section and FOC (Chi square $=0.619, \mathrm{p}=0.43)$.

Table 3: Tokophobia in relation to request for caesarean section.

\begin{tabular}{|c|c|c|c|}
\hline \multirow{2}{*}{ Parameters } & Areskog's score & Parameters & \multirow{2}{*}{ Total } \\
\hline & FOC & No FOC & \\
\hline Women with request for caesarean section, $\mathbf{N}(\%)$ & $11(47.8)$ & $12(52.2)$ & $23(100.0)$ \\
\hline Tokophobia, $(\%)$ & 13.3 & 17.9 & 15.3 \\
\hline Women who don't request for caesarean section, $\mathbf{N}(\%)$ & $72(56.7)$ & $55(43.3)$ & $127(100.0)$ \\
\hline Tokophobia, (\%) & $86.7 \%$ & $82.1 \%$ & $84.7 \%$ \\
\hline Total, N (\%) & $83(55.3)$ & $67(44.7)$ & $150(100)$ \\
\hline Tokophobia, (\%) & 100.0 & 100.0 & 100.0 \\
\hline
\end{tabular}

Table 4: Tokophobia and variation with educational status.

\begin{tabular}{|c|c|c|c|}
\hline \multirow{2}{*}{ Education } & \multicolumn{2}{|c|}{ Areskog's score } & \multirow{2}{*}{ Total } \\
\hline & Positive & Negative & \\
\hline Intermediate & 82 & 37 & 119 \\
\hline Graduate & 17 & 9 & 26 \\
\hline Postgraduate & 4 & 1 & 5 \\
\hline Total & 83 & 67 & 150 \\
\hline
\end{tabular}

Table 5: Tokophobia in relation to parity.

\begin{tabular}{|lll|}
\hline Parameters & Nulliparous & Multiparous \\
\hline $\begin{array}{l}\text { Positive for } \\
\text { tokophobia (N) }\end{array}$ & 46 & 36 \\
\hline $\begin{array}{l}\text { Negative for } \\
\text { tokophobia (N) }\end{array}$ & 47 & 21 \\
\hline Present study (\%) & 49.46 & 64.1 \\
\hline
\end{tabular}

Table 6: Comparative with published reports.

\begin{tabular}{|c|c|c|}
\hline Parameters & Nulliparous (\%) & Multiparous (\%) \\
\hline Rouhe et al ${ }^{13}$ & 42.6 & 57.4 \\
\hline Rouhe et al ${ }^{14}$ & 43.3 & 56.7 \\
\hline $\begin{array}{l}\text { Present } \\
\text { study }\end{array}$ & 49.46 & 64.1 \\
\hline
\end{tabular}

\section{Limitations}

The limitation of the study was an absence of a universally accepted questionnaire to assess tokophobia, as several studies have used different scales for different components and factors influencing tokophobia. Partners of the sample population were not involved in assessing the factors influencing FOC.

\section{CONCLUSION}

Tokophobia is associated with most pregnant women in different severity. Secondary tokophobia is commoner than primary tokophobia. Fear of childbirth is influenced by sociodemographic variables like educational status and socioeconomic status. With improved sociodemographic conditions, there might be a scope for reduction in tokophobia.

\section{Recommendations}

Concerns in assessing and treating tokophobia might avert the indication of on request caesarean section arising out of FOC. Structured treatment protocol is necessary to reduce FOC in multiparous women as they stand at more chance of vaginal delivery if they permit, than their nulliparous counterparts.

Funding: No funding sources

Conflict of interest: None declared

Ethical approval: The study was approved by the Institutional Ethics Committee

\section{REFERENCES}

1. Bhatia MS, Jhanjee A. Tokophobia: A dread of pregnancy. Ind Psychiatry J. 2012;21(2):158-9.

2. Melender HL. Experiences of fears associated with pregnancy and childbirth: A study of 329 pregnant women. Birth. 2002;29:101-11.

3. Hofberg K, Ward MR. Fear of pregnancy and childbirth. Postgrad Med J. 2003;79:505-10.

4. Alehagen S, Wijma K, Wijma B. Fear during labor. Acta Obstet Gynecol Scand. 2001;80:315-20.

5. Billert H. Tokophobia--a multidisciplinary problem.Ginekol Pol. 2007;78(10):807-11.

6. Saisto T, Halmesmäki E. Fear of childbirth: a neglected dilemma. Acta Obstet Gynecol Scand. 2003;82(3):201-8. 
7. Melender HL. Experiences of fear associated with pregnancy and childbirth. Birth 2002;29:101-11.

8. Kristina H, Ian B. Tokophobia: an unreasoning dread of childbirth . A series of 26 cases. British J Psychiat. 2000;176:83-5.

9. Rouhe H, Salmela-Aro K, Gissler M, Halmesma“ki E, Saisto T. Mental health problems common in women with fear of childbirth. BJOG. 2011;118:1104-11.

10. Kola ST, Hofoss D, Daltveit AK. Indications for caesarean deliveries in Norway. Am J Obstet Gynecol. 2003;188:864-70.

11. Hilde N, Lotta H, Tore S, Pal $\varnothing$. Maternal request for caesarean section due to fear of birth: can it be changed through crisis-oriented counseling?. Birth. 2006;33:221-8.

12. Katarina S, Sanna R, Hanna R, Erja H, Maiju I, Rukka A. Promoting positive motherhood among nulliparous women with intense fear of childbirth: RCT intervention . J Health Psychol. 2011;17(4)52034.
13. Rouhe H, Salmela-Aro K, Halmesma ki E, Saisto T. Fear of childbirth according to parity, gestational age, and obstetric history. BJOG. 2009;116:67-73.

14. Rouhe H, Salmela-Aro K, Gissler M, Halmesma“ki E, Saisto T. Mental health problems common in women with fear of childbirth. BJOG. 2011;118:1104-11.

15. Gunilla S, Louise A, Sofie P, Marie B, Adam S, Ann J. Secondary fear of childbirth prolongs the time to subsequent delivery. Acta Obstet Gynecol Scand. 2013;92:210-4.

Cite this article as: Ramalingappa $\mathrm{P}$, Gowda RS, Srinivasamurthy SH. A study of factors associated with tokophobia and its effect on pregnancy. Int J Reprod Contracept Obstet Gynecol 2022;11:798-802. 